\title{
Sustainability of the Concrete Industry - current Trends and Future Outlook
}

\author{
NIKOLA D. TOŠIĆ, University of Belgrade, \\ Faculty of Civil Engineering, Belgrad \\ SNEŽANA B. MARINKOVIĆ, University of Belgrade, \\ Faculty of Civil Engineering, Belgrade \\ ALEKSANDAR S. STOJANOVIĆ, International University \\ College of Turin, Torino, Italy
}

\author{
Review paper \\ UDC: 666.972 .12 \\ 628.477.6.043:691.32
}

DOI: 10.5937/tehnika1701038T

Achieving sustainability of all human actions has been recognized as an urgent and top priority since the warnings of anthropogenic climate change are overwhelming. However, the precise goal, aim and method of shifting the global paradigm towards sustainability are still contested.

Among all human activities, the concrete industry has one of the largest environmental footprints, not only because concrete is the second most used material in the world, but also because the production of cement for concrete is highly energy-intensive and inevitably releases large amounts of $\mathrm{CO}_{2}$.

In this paper, a historic and theoretical background to the environmental problems, arising from the production and use of concrete, is presented. The specific problems it poses are recognized as natural resource consumption, $\mathrm{CO}_{2}$ emissions, and waste generation. A technical discussion based on Life Cycle Assessment analyses is presented alongside a societal interpretation within the framework of common resource and externality management.

Possible technical solutions in the form of recycling waste concrete and replacing cement with industrial by-products are presented and finally, a necessity for a shift towards a holistic and environmental paradigm is highlighted.

Key words: sustainability, concrete, $\mathrm{CO}_{2}$, cement, waste, recycled concrete aggregate, fly ash

\section{INTRODUCTION}

Sustainability, as a keyword in many areas, has become ever present in our society today. However, the precise meaning of the term is often misunderstood or unclear. The Rio Declaration from 1992 states as its first principle that "Human beings are at the centre of concerns for sustainable development" [1]. Sustainability can then be seen as an endeavour to maintain the species Homo sapiens.

Humankind has actually come so far that it has emerged as a geological force shaping the environment. The International Commission on Stratigraphy has started deliberating a proposal to proclaim a new geological epoch-the Anthropocene-which would be considered to have started between the Industrial revolution and the end of World War II [2]. Mankind is

Author's address: Nikola Tošić, University of Belgrade, Faculty of Civil Engineering, Belgrade, Bulevar kralja Aleksandra 73, n.tosic@imk.grf.bg.ac.rs

Paper received: 10.01.2017.

Paper accepted: 13.01.2017. making an impact on the planet that will be felt for millennia, and in the process endangering its own existence and the existence of other species.

A significant way in which our impact is realized is through the built environment-through the structures we build and use.

The construction industry itself is responsible for one of the largest impacts of all human activities: $40 \%$ of raw stone, gravel and sand consumption, $25 \%$ of virgin wood, $40 \%$ of total energy and $16 \%$ of annual water consumption [3].

\section{BACKGROUND}

Concrete is the material of the modern build environment. It is, in fact, the most widely used man-made material in the world with a global annual production of up to 20 billion tons [4]. It reached its current status in less than 200 years. Even though early finding suggest types of concrete were used in many ancient civilizations - from Egypt to Rome - the modern story of concrete begins in the $18^{\text {th }}$ century and the patent for Portland cement obtained by Johnson Aspden in 1824 
[5]. Shortly afterwards came the invention of reinforced and prestressed concrete (1850-1920) [5]. The development was finalized in the second half of the $20^{\text {th }}$ century with the invention of superplasticizers, fibre reinforcement and ultra-high strength concretes.

The large annual production of concrete consequently leads to an equally large consumption of component materials - annually around 15 billion tons of aggregates and 4.2 billion tons of cement [6], [7].

One of the greatest environmental problems arising from the concrete industry are the large $\mathrm{CO}_{2} \mathrm{emi}-$ ssions from cement production. On average, per each $\mathrm{kg}$ of cement, approximately $700-900 \mathrm{~g}$ of $\mathrm{CO}_{2}$ is released [8], [9]. In total, this amounts to 5-7\% of all anthropogenic $\mathrm{CO}_{2}$ emissions. Although the cement industry is moving toward using renewable energy sources in their production process, the chemical reaction of calcination requires an inevitable release of $\mathrm{CO}_{2}$.

$$
\mathrm{CaCO}_{3}+\text { ?eat } \rightarrow \mathrm{CaO}+\mathrm{CO}_{2}
$$

Hence, there is a natural limit to how much these emissions can be decreased.

Beside this problem related to the production of concrete, there is another one related to the end-of-life phase of concrete structures. After their service life expires - due to whatever reason - concrete structures are demolished. In this way, large quantities of construction and demolition waste (CDW) are generated. In the EU alone, 850 million tons of CDW are generated annually, accounting for around 30\% of total waste [10]. A large part of this waste is demolished concrete and the main method of dealing with it is still landfilling.

\section{TECHNICAL CONTEXT}

The quantitative aspect of concrete's (un)sustainability is well documented. This is mostly done through Life Cycle Assessment (LCA) studies. LCA is a methodology for evaluating the environmental load of processes and products during their life cycle [11]. When studying concrete, LCA is used to quantify and compare the emissions to air, ground and water arising during the life cycle of different concretes. Varying approaches can be taken in LCA, taking into account different parts of concrete's life cycle in so-called cradle-to-grave, cradle-to-gate or gate-to-gate scenarios, Figure 1.

After choosing a scenario, data must be gathered about the studied processes, preferably for the location which is being examined. Collected data should include energy consumption and emissions of gases. This is done for all the life cycle stages; in the case of Figure 1, for cement, aggregate and concrete production and transport.

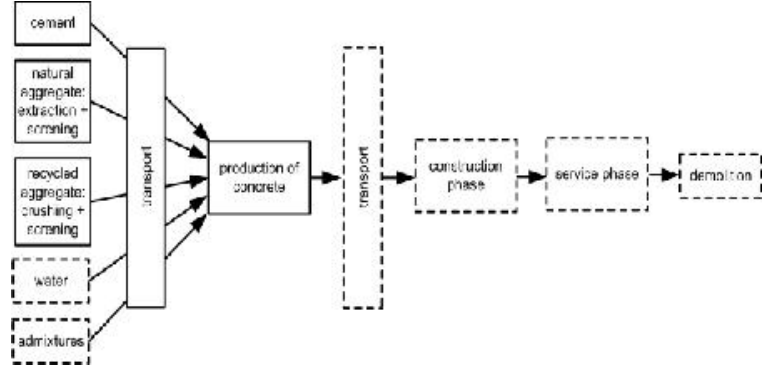

Figure 1 - A cradle-to-gate scenario in LCA

In the end, emissions are compiled into several impact categories. One of the most important ones in LCA is the global warming potential, expressed in grams of $\mathrm{CO}_{2}$-equivalent (a compound metric of $\mathrm{CO}_{2}$ and other greenhouse gases). Other impact categories include the potential for acidification, eutrophication, ozone depletion, abiotic resource depletion, etc. They can also be related to damages to human health, such as Disability Adjusted Life Years, a World Health Organization measure of how many years of healthy life have been lost [8], [12].

When looking at all LCA studies regarding concrete, one conclusion stands out - cement production is responsible for a lion's share of the environmental impact caused during all life cycle phases. In almost all impact categories, cement production is responsible for $60-90 \%$ of the environmental load; transport comes at a distant second place [8], [13], [14].

The unavoidable $\mathrm{CO}_{2}$ emissions from cement production, combined with its large annual production are a recipe for environmental problems. The cement industry is a highly agglomerated and corporatized industry. Table 1 presents the data for top five cement producing countries. The main conclusion drawn from the data is that cement production in China is almost five times larger than the other countries combined.

Table 1. Top five cement producing countries in 2014 [15].

\begin{tabular}{|l|l|l|}
\hline Rank & Country & $\begin{array}{l}2014 \text { cement production } \\
(\mathrm{Mt})\end{array}$ \\
\hline 1 & China & 2500 \\
\hline 2 & India & 280 \\
\hline 3 & USA & 83.3 \\
\hline 4 & Iran & 75.0 \\
\hline 5 & Turkey & 75.0 \\
\hline
\end{tabular}

In large part, this has to do with China's fast economic development in which it is catching up with developed countries. However, cement demand is also high because of the urbanization concept adopted by the Chinese government - whole cities are built "from scratch" and then populated. This type of state-planned urbanization leads to a high cement demand because it 
relies on high-rise apartment buildings (usually cement-intensive), rather than relying on a more organic development of the city, e.g. building low-rise houses in suburbs (which can be built from masonry or wood).

What are the outlooks that cement demand will stabilize or decrease in the future? In 2002, Mahasenan et al. looked at the correlations between cement demand, gross domestic product (GDP) and population of developed and developing countries [16]. They found that per capita cement demand was proportional to per capita GDP up to approximately US\$8,000 (expressed in 1990 dollars; ca. US\$13,000 in 2016 dollars), after which it became proportional to the total population [16].

By analysing demand data for several countries they obtained the following equation

$$
\text { Demand }=\frac{A X^{-\gamma}+B X^{\gamma}}{X^{-\gamma}+X^{\gamma}}
$$

Where $A=\alpha$ GDP (demand proportional to GDP at low incomes), $B=\beta$ population (demand proportional to population at high incomes), $X=$ per capita GDP (scaled to US\$8,000), and $\gamma=$ shape parameter.

According to World Bank data, the per capita GDP of China (in 2016 dollars) is just over US\$8,000 [17]. Hence, if the model is accurate, cement demand will further increase to even larger levels and then stabilize at those high levels because of China's large population. This problem is slowly being realized and addressed by researchers [18].

The other large and often overlooked problem that LCA studies point to is the end-of-life of concrete structures. The large amounts of CDW being generated are still mainly being landfilled, with the exception of several developed countries that have a shortage of natural aggregates (NA), e.g. the Netherlands, or very limited landfilling capacities, e.g. Japan. Although CDW waste is generally inert and not toxic, the shear amounts of it are causing environmental concerns, especially because it tends to be generated and concentrated near urban centres.

Since a large portion of the built environment in the developed countries is approaching the end of its service life (e.g. most of Europe's infrastructure was built after World War II), the problem is only expected to get more serious.

Having in mind these issues, the scientific community has worked for several decades to identify areas in which improvements can be made. One approach which deals with two problems simultaneously is recycling of CDW. Waste concrete cannot be recycled back into its original constituent materials nor original form. Concrete can be crushed into aggregates called recycled concrete aggregates (RCA) which can be used in new applications. On the one hand, using RCA lowers demand for natural aggregates and on the other, reduces the amount of $\mathrm{CDW}$.

Another approach is concentrated on reducing concrete's environmental impact through the reduction of cement use. This is mainly achieved by using so-called supplementary cementitious materials, of which the most widespread are blast furnace slag (a by-product of steel production) and fly ash (a by-product of coal combustion). They can be used to replace a certain percentage of cement or they can be used in concretes produced completely without cement in which these materials are "activated" with alkali solutions to produce alkali-activated concretes.

The production of RCA is carried out in mobile or stationary facilities and usually involves a two-stage crushing and sieving process and a removal of any impurities such as steel, wood, gypsum, masonry, glass, etc. Since concrete consists of NA bound by hardened cement paste, after recycling a certain amount of this "residual cement paste" is left bound to the aggregates.

This means that RCA is actually a two-phase material containing natural aggregates and cement paste. The presence of this residual cement paste causes a certain deterioration of RCA properties such as higher porosity and water absorption between 3.5 and $10 \%$ (compared with only around $1 \%$ in the case of NA) [19], [20].

Because of this, RCA is still mainly considered to be inferior compared to NA and is relegated to use in applications such as road sub-base and nonstructural elements. However, the positive effects of concrete waste recycling can be fully utilized only if recycled concrete aggregates find their use in all types of concrete. Concrete made with RCA is called recycled aggregate concrete (RAC).

The replacement of NA can be total $(100 \%)$ or partial $(<100 \%)$. The applicability of RCA and the properties of RAC have been studied for several decades [21]. More and more, RAC is being investigated on both macroscopic and microscopic levels. Mechanical and durability-related properties are being tested as well as the structural behaviour of full-scale elements such as beams, columns or slabs [22], [23].

Using LCA, various authors have compared recycled aggregate concrete to natural aggregate concrete (NAC). In [8], the authors reported that the same environmental impacts for both concretes can be obtained only if the transport distances of RCA are smaller than the transport distances of NA.

The authors of [24] found that if the additional amount of cement used in RAC (justified by weaker properties of RCA compared to NA) is below $10 \%$, the impacts from NAC and RAC will be comparable. In 
[25], a multi-criteria optimization method was employed to find the best choice of concrete type (between NAC, RAC with $50 \%$ and $100 \%$ of coarse aggregate replacement) taking into account economic and environmental criteria and found RAC with $50 \%$ replacement to be the optimal choice in all criteria ranking scenarios.

All of these results point to potential environmental benefits of using RCA in concrete. However the production of RCA in recycling facilities is far from a developed industry. The economic viability of RAC use was broadly studied and discussed. The case of Ireland was analyzed in [26]. Under the assumptions of perfect competitiveness of the recycling centres and no possibilities of illegal C\&D waste disposal, the authors found that economic viability will occur when the cost of landfilling exceeds the cost of transporting waste to the recycling centre and the cost of using NA exceeds the cost of using RCA.

Recycling centres were shown to benefit from economies of scale. Both studies [26] and [25] advocate the enforcement of the ,polluter pays" principle and find market based instruments such as increases in landfill taxes, subsidies on recycled aggregates and taxes on the use of natural aggregates to be the best option for policy makers in incentivizing the recycling industry. As for the operation of the recycling facility itself, in the case of Portugal it was found that they can be profitable with a return on investment period under 8 years in all cases of a sensitivity analysis [27], [28].

As for reducing cement use in concrete, the World Bank data show that in $201341.3 \%$ of total electricity produced came from coal sources i.e. coal burning thermal power plants [17]. As a result large amounts of fly ash, a by-product of coal combustion, are being generated worldwide. The U.S. produces roughly 131 million tons of fly ash each year, China and India 300 million tons [29].

Fly ash, as well as a number of other industrial byproducts, consists mainly of silicon and aluminium oxides and has pozzolanic properties which means it reacts with cement hydration products and enforces the paste matrix, contributing to the properties of the final material. Hence, it is reasonable to assume that a replacement of a certain amount of cement by fly-ash will not have adverse effects on concrete.

Such concretes in which more than $30 \%$ of cement is replaced by fly ash are called high-volume fly ash concretes (HVFAC). Because the pozzolanic reaction is slower than cement hydration HVFAC exhibits slower strength development than ordinary cement concrete which has to be taken into account [30]. The benefits of using fly ash include better workability due to a finer packing density of particles and improvement of certain durability-related and long-term properties such as shrinkage.

However, since fly ash is a by-product of coal combustion and effectively of electricity production it is no longer considered to be a waste material [31]. Therefore, in LCA analyses a certain amount of emissions from electricity production has to be allocated to FA. Whether this is done according to "mass" or "economic" allocation, it worsens the environmental performance of HVFAC relative to NAC [32].

\section{SOCIO-ECONOMIC CONTEXT}

It seems that today the world is faced with a particular challenge $\left(\mathrm{CO}_{2}\right.$ emissions from cement production and disposal of demolished concrete structures) but also that technical means to overcome it have been developed ("green" alternatives). At the same time, it can be seen that these technical solutions are rare and limited in their effect. The question is then, "Why are policy makers not reacting to the conclusions reached by the scientific community?"

In his 1968 article "The Tragedy of the Commons", Garrett Hardin famously pointed out that there is a class of human problems that could be classified as so-called "no technical solution problems". These are problems which cannot be overcome by mere tweaks and adjustments in technical sciences and without any changes in human values or ideas [33].

This is obvious when looking at the debate surrounding sustainability and sustainable development (the kind of development that should be pursued in order to achieve sustainability) [34]. From the point of view of biophysical concerns, sustainable development is a purely anthropocentric problem. Hence, one's interpretation of this topic will be highly influenced by his value system-ranging from a utilitarian to a more spiritual worldview [35].

A distinction exists between "strong" and "weak" sustainability. For proponents of weak sustainability all forms of "natural capital" (i.e. products of nature) are commensurable with and can be substituted by human-made capital (i.e. products of human labour), while the supporters of strong sustainability argue that some natural capital stocks are incommensurable and not substitutable by human-made capital [35].

In the case of the concrete industry, the standpoint of weak sustainability implies free, unregulated cement production under the assumption that the harm due to $\mathrm{CO}_{2}$ emissions is reversible. This assumption is clearly unrealistic, since the concrete industry is so specific that even the green alternatives cannot radically diminish the ecological footprint.

This proves that following the logic of weak sustainability, questions are raised whether the 
Western model of development may run up against social and political limits before reaching environmental planetary constraints [36]. This means that thinking about the way that the challenge of sustainability has to be approached necessitates considering a more general context. It is established that "sustainable" is more than just ecological (i.e. based on the measurement of climate change). It pertains to a set of important normative issues and particularly equality. In the case of sustainable concrete it is necessary to put the previous analysis in a broader context of social values that sustainability implies.

The relevant broader context of sustainability also implies that the pervasive emphasis on "development" and "growth" as the world's panacea, all too often takes on the form of knowledge, capital and technology transfer and export from developing to developed countries, i.e. the further accumulation of capital by the core developed countries with no regard to the specifics of each country and to what sustainable practices already exist within them [37].

In underdeveloped economies, utilized technologies are usually a generation old, bought from the developers in the developed countries. At the same time, the existing research capacities are not used for development of technology at home. For example, in many of these economies the practice of using municipal waste as a source of energy instead of coal in cement plants is only now beginning to be implemented.

Ofcourse, Hardin's question of what has to be changed for the appropriate technology to be utilized stays unanswered. The potential of regulation is not implemented as it is something that would make the countries less attractive to investment, which leads to difficulties for countries that already find themselves in economic turmoil.

Looking at actual policy attempts of considering the construction and concrete industries in this broader context, the findings are hardly satisfying. The fact is that policy response to the structural problems of pollution and particularly the solution to problems related to concrete have not been adequate [31], [38].

The existing interstate framework is founded on the idea of the protection of rights in the context of multiple sovereign states [39]. Because of this it has been limited to problems that do not put this sovereignty into question. In reality this limitation has excluded the possibility of any regulatory attempts that would be imposed with an eye on the global character of the problem.

All of them would intervene in the domain of private law issues of sovereign states [40]. This implies that the problem of pollution and construction also leads to an inquiry about which actor would be able to tackle the structural problems on a global scale.

\section{FUTURE OUTLOOK}

This paper tried to briefly present a technical and socio-economic context for the concrete industry within the broader global sustainability debate. The true potential of sustainability can only be realized if it acts as an integrating concept [35]. This was the aim of this study, to present all sides of the story and enable an integrating discussion to be started and conclusions to be drawn.

It is becoming clearer that the interrelatedness of these dimensions implies that even though the solution of the problems will be a result of a precise and close focus on each of them, they cannot be separated fully and that they will have to be approached in their interconnectedness. A "paradigm shift" is needed from a mechanistic to a holistic and ecological worldview [41].

From this realization slowly arises a new $R \& D$ agenda that is attempting to encompass all the enablers and actions necessary for carrying out the paradigm shift [34].

Technology enablers are the physical infrastructure, systems, models and know-how; institutional enablers are national and local governments, planning and implementing agencies, academic and research institutions and professional associations; value enablers are the personal codes of conduct and community behaviours. Together, they have tasks and actions to perform in search of this common goal of achieving sustainability [34].

Hopefully, the contribution of this study will be to present concisely ideas and data about the concrete industry necessary for participating in the debate about its future and ultimately, our planet's future.

\section{ACKNOWLEDGMENT}

The work reported in this study is a part of the investigation within the Research Project TR36017: "Utilization of by-products and recycled waste materials in concrete composites in the scope of sustainable construction development in Serbia: investigation and environmental assessment of possible applications", supported by the Ministry for Education, Science and Technology, Republic of Serbia. This support is gratefully acknowledged.

\section{REFERENCES}

[1] United Nations Environment Programme (UNEP), 1992 Rio Declaration on Environment and Development. Rio de Janeiro: United Nations Environment Programme (UNEP), 1992. 
[2] Subcommission on Quaternary Stratigraphy, "Working group on the "Anthropocene," 2016. [Online]. Available: http://quaternary.stratigraphy.org/workinggroups/anthropocene/. [Accessed: 26-Dec-2016].

[3] M. K. Dixit, J. L. Fernandez-Solis, S. Lavy, and C. H. Culp, "Identification of parameters for embodied energy measurement: A literature review," Energy Build., vol. 42, no. 8, pp. 1238-1247, 2010.

[4] WBCSD, "The Cement Sustainability Initiative," World Business Council for Sustainable Development, 2009. [Online]. Available: http://www.wbcsdcement.org/pdf/CSIRecyclingConcreteFullReport.pdf. [Accessed: 07-Jul-2016].

[5] M. Aćić, "The history and development of reinforced concrete in Europe and the world with an overview of the conditions in the Kingdom of Serbia," in One hundred years of teaching reinforced concrete at the University of Belgrade's Faculty of Civil Engineering, M. Aćić and S. Marinković, Eds. Belgrade: Faculty of Civil Engineering, University of Belgrade - Institute of Materials and Structures, 2012, pp. 1337.

[6] W. H. Langer, L. J. Drew, and J. J. Sachs, “Aggregate and the Environment," Alexandria, VA, 2004.

[7] USGS, "Minerals Yearbook," US Geological Survey, 2015. [Online]. Available: minerals.usgs.gov/minerals/pubs/commodity/cement/mcs-2015-cement.pdf. [Accessed: 07-Jul-2016].

[8] S. Marinković, V. Radonjanin, M. Malešev, and I. Ignjatović, "Comparative environmental assessment of natural and recycled aggregate concrete," Waste Manag., vol. 30, pp. 2255-2264, 2010.

[9] H. S. Müller, M. Haist, and M. Vogel, “Assessment of the sustainability potential of concrete and concrete structures considering their environmental impact, performance and lifetime," Constr. Build. Mater., vol. 67, pp. 321-337, 2014.

[10]C. Fisher and M. Werge, "EU as a Recycling Society," ETC/SCP Working Paper 2, 2011. [Online]. Available: scp.eionet.europa.eu/wp/ETCSCP 2per2011. [Accessed: 07-Jul-2016].

[11]ISO 14040, Environmental management - Life Cycle assessment - Principles and framework. Geneva: International Organization for Standardization, 2006.

[12]P. Van Den Heede and N. De Belie, "Environmental impact and life cycle assessment (LCA) of traditional and 'green' concretes: Literature review and theoretical calculations," Cem. Concr. Compos., vol. 34, pp. 431-442, 2012.

[13]M. De Schepper, P. Van den Heede, I. Van Driessche, and N. De Belie, "Life Cycle Assessment of Completely Recyclable Concrete," Materials (Basel)., vol. 7, pp. 6010-6027, 2014.
[14]T. Ding, J. Xiao, and V. W. Y. Tam, “A closed-loop life cycle assessment of recycled aggregate concrete utilization in China," Waste Manag., vol. 56, pp. 367-375, 2016.

[15]A. Saunders, "Preview: The top 100 global cement companies and global per capita capacity trends," Global Cement Magazine, 2015. [Online]. Available: www.globalcement.com/magazine/articles/964-preview-the-top-100-global-cement-companies-andglobal-per-capita-capacity-trends. [Accessed: 07-Jul2016].

[16]N. Mahasenan, S. Smith, and K. Humphreys, "The Cement Industry and Global Climate Change: $\mathrm{Cu}$ rrent and Potential Future Cement Industry $\mathrm{CO} 2$ Emissions," in Greenhouse Gas Control Technologies, Volume III, 2002, pp. 995-1000.

[17]World Bank, "World Bank Indicators," 2016. [Online]. Available: http://data.worldbank.org/indicator. [Accessed: 07-Jul-2016].

[18]J. H. Xu, T. Fleiter, Y. Fan, and W. Eichhammer, " $\mathrm{CO} 2$ emissions reduction potential in China's cement industry compared to IEA's Cement Technology Roadmap up to 2050," Appl. Energy, vol. 130, pp. 592-602, 2014.

[19]K. Rahal, "Mechanical properties of concrete with recycled concrete aggregates," Build. Environ., vol. 42, no. 1, pp. 407-415, 2007.

[20]J. Xiao, J. Li, and C. Zhang, "Mechanical properties of recycled aggregate concrete under uniaxial loading," Cem. Concr. Res., vol. 35, pp. 1187-1194, 2005.

[21]P. J. Nixon, "Recycled concrete as an aggregate for concrete - a review," Mater. Struct., vol. 11, pp. 371378, 1978.

[22]J. Xiao, C. Q. Wang, J. Li, and M. Tawana, "Shaketable model tests on recycled aggregate concrete frame structure," ACI Struct. J., vol. 109, no. 6, pp. 777-786, 2012.

[23]I. Ignjatović, S. Marinković, Z. Mišković, and A. Savić, "Flexural behavior of reinforced recycled aggregate concrete beams under short-term loading," Mater. Struct., vol. 469, no. 6, pp. 1045-1059, 2013.

[24]C. Knoeri, E. Sanyé-Mengual, and H.-J. Althaus, "Comparative LCA of recycled and conventional concrete for structural applications," Int. J. Life Cycle Assess., vol. 18, no. 5, pp. 909-918, 2013.

[25]N. Tošić, S. Marinković, T. Dašić, and M. Stanić, "Multicriteria optimization of natural and recycled aggregate concrete for structural use," J. Clean. Prod., vol. 87, pp. 766-776, 2015.

[26]X. Duran, H. Lenihan, and B. O'Regan, “A model for assessing the economic viability of construction and demolition waste recycling - the case of Ireland," 
Resour. Conserv. Recycl., vol. 46, no. 3, pp. 302-320, 2006.

[27]A. Coelho and J. De Brito, "Economic viability analysis of a construction and demolition waste recycling plant in Portugal - Part I: Location, materials, technology and economic analysis," J. Clean. Prod., vol. 39, pp. 338-352, 2013.

[28]A. Coelho and J. De Brito, "Economic viability analysis of a construction and demolition waste recycling plant in Portugal - Part II: Economic sensitivity analysis," J. Clean. Prod., vol. 39, pp. 329337, 2013.

[29]V. M. Malhotra, "High performance high-volume fly ash concrete for sustainable development," in International Workshop on Sustainable Development and Concrete Technology, 2004, pp. 3-14.

[30]J. Dragaš, N. Tošić, I. Ignjatović, and S. Marinković, "Mechanical and time-dependent properties of highvolume fly ash concrete for structural use," Mag. Concr. Res., vol. 68, no. 12, pp. 632-645, 2016.

[31]European Union, "Directive 2008/98/EC of the Europian parliament and of the council on waste and repealing certain directives," Off. J. Eur. Union, vol. L312, pp. 3-30, 2008.

[32]S. Marinković, G. Habert, I. Ignjatović, J. Dragaš, N. Tošić, and C. Bruamud, "Life Cycle Analysis of Recycled Aggregate Concrete With Fly Ash as Partial Cement Replacement," in Sustainable Built Environment (SBE) Regional Conference, 2016, pp. $1-7$.
[33]G. Hardin, “The Tragedy of the Commons," Science (80-. )., vol. 162, no. 3859, pp. 1243-1248, 1968.

[34]C. Du Plessis, Agenda 21 for: Sustainable construction in developing countries - a discussion document. Pretoria: CSIR Building and Construction Technology, 2002.

[35]J. Robinson, "Squaring the circle? Some thoughts on the idea of sustainable development," Ecol. Econ., vol. 48, no. 4, pp. 369-384, 2004.

[36]F. Hirsch, Social Limits to Growth. Cambridge, Massachusets: Harvard University Press, 1976.

[37]C. Du Plessis and R. J. Cole, "Motivating change: shifting the paradigm," Build. Res. Inf., vol. 39, no. 5, pp. 436-449, 2011.

[38]UNEP, "The 10YFP Programme on: Sustainable Buildings and Construction Programme," 2015. [Online]. Available: http://www.unep.org/10yfp/Portals/50150/Brochure 10YFP SBC Programme.pdf. [Accessed: 07-Jul-2016].

[39]J. Klabbers, International Law. Cambridge: Cambridge University Press, 2013.

[40]P. Levin, Construction Contract Claims, Changes \& Dispute Resolution. American Society of Civil Engineers, 1998.

[41]C. Du Plessis and P. Brandon, "An ecological worldview as basis for a regenerative sustainability paradigm for the built environment," J. Clean. Prod., vol. 109, pp. 53-61, 2015.

\section{REZIME}

\section{ODRŽIVOST INDUSTRIJE BETONA - SAVREMENI TRENDOVI I IZGLEDI ZA BUDUĆNOST}

Postizanje održivosti svih ljudskih aktivnosti je prepoznato kao hitan i prioritetan zadatak s obzirom da su upozorenja o ljudskim uzrocima klimatskih promena brojna. Međutim, tačan cilj i način promene globalne paradigme ka održivosti su i dalje nejasni i neusaglašeni.

Od svih ljudskih aktivnosti, industrija betona ima jedan od najvećih uticaja na životnu sredinu, ne samo usled toga što je beton drugi najkorišćeniji materijal na svetu, već i usled toga što je proizvodnja cementa energetski veoma zahtevna i neizbežno dovodi do emisije velikih količina $\mathrm{CO}_{2}$.

U ovom radu su predstavljeni istorijski podaci i teorijske osnove ekoloških problema koji nastaju usled proizvodnje betona. Konkretni problemi do kojih dolazi su potrošnja prirodnih resursa, emisije $\mathrm{CO}_{2} i$ proizvodnja otpada. Tema rada je predstavljena sa tehničkog aspekta na osnovu analiza životnog ciklusa, a društveno-ekonomska interpretacija je data u teorijskom okviru upravljanja zajedničkim dobrima i eksternalijama.

Predstavljena su moguća tehnička rešenja u vidu recikliranja otpadnog betona $i$ zamene cementa industrijskim nusproizvodima. Na kraju je ukazano na potrebu za zaokretom globalne paradigme ka holističkom i ekološkom pogledu na svet.

Ključne reči: održivost, beton, $\mathrm{CO}_{2}$, cement, otpad, reciklirani agregat, leteći pepeo 